\title{
The potential immunogenicity of human insulin and insulin analogues evaluated in a transgenic mouse model
}

\author{
J. L. Ottesen ${ }^{1}$, P. Nilsson ${ }^{1}$, J. Jami ${ }^{2}$, D. Weilguny ${ }^{1}$, M. Dührkop ${ }^{1}$, D. Bucchini ${ }^{2}$, S. Havelund ${ }^{3}$, J. M. Fogh ${ }^{1}$ \\ ${ }^{1}$ Molecular and Cellular Biology, Biopharmaceuticals Division, Novo Nordisk, Gentofte, Denmark \\ ${ }^{2}$ Physiological Genetics Laboratory, Institut National de la Santé et de la Recherche Médicale U.257, Cochin Institute of \\ Molecular Biology, Cochin Hospital, University of Paris V, Paris, France \\ ${ }^{3}$ Department of Biophysical Chemistry, Diabetes Care Division, Novo Nordisk, Bagsvaerd, Denmark
}

\begin{abstract}
Summary Transgenic mice with tissue-specific expression of the human insulin gene in the beta cells of the pancreas do not produce insulin-specific antibodies when injected with human insulin. Tolerant transgenic mice injected with human or porcine insulin reflect the clinical situation. When injected with bovine insulin the transgenic mice produce antibodies. The potential immunogenicity of 12 recombinant human insulin analogues has been tested in this transgenic model. The analogues were designed either to prevent hexamer formation or to improve chemical stability or both. The analogues have amino acid substitutions or deletions at residue 8,10 and 21 in the A-chain and residue 3, 9, 27 and 28 in the B-chain. The results show that substitution of single amino acids in the A-chain loop of human insulin for the corresponding amino acids in bovine insulin at residues $\mathrm{A} 8$ or $\mathrm{A} 10$ is sufficient to elicit an antibody
\end{abstract}

response in responder mice. Only human insulin analogues with substitutions at residues 8 or 10 in the Achain elicit antibody formation in the transgenic mice, whereas non-transgenic control groups respond to insulin and all analogues. Antibodies developed against the human insulin analogues are cross reactive with recombinant human insulin. Antibodies developed against an immunogenic analogue could therefore neutralize both the analogue and the native insulin and thereby aggravate the patient's condition. This transgenic mouse immunogenicity model should be useful as an in vivo model to map immunogenic areas of recombinant proteins. [Diabetologia (1994) 37: 1178-1185]

Key words Transgenic mice, tolerance, insulin, analogue, immunogenicity.
With the widespread use of recombinant DNA technology it has become common to produce second generation products (analogues) with altered in vivo characteristics, e.g., half-life, receptor binding affinity, stability, and absorption rate. Antibodies toward proteins administered for therapeutic purposes have been reported to play a role in allergic reactions and

Received: 4 March 1994

and in final revised form: 9 June 1994

Corresponding author: Dr. J.L. Ottesen, Department of Gene Technology and Virology, Novo Nordisk, Niels Steensensvej 1, DK-2820 Gentofte, Denmark

Abbreviations: MHC, Major histocompatibility complex; PCR, polymerase chain reaction; OD, optical density; htPA, human tissue plasminogen activator; RIA, radioimmunoassay. lipoatrophy at the injection site [1]. Moreover, antibodies directed against epitopes on the analogue could cross react with epitopes on the corresponding endogenous protein and lead to a neutralizing effect of both the analogue and the endogenous protein [2]. It is important to evaluate whether or not the administration of such analogues results in antibody formation in patients. It would be useful to have a model where the potential immunogenicity of analogues, to be used in clinical trials, could be evaluated. Such a model would also avoid extensive research on analogues that, though they possess outstanding advantages in vivo, would be ultimately discarded because they are immunogenic in patients.

The immune response to insulin in mice is under the control of MHC class II genes in the $\mathrm{H}-2$ region on chromosome $17[3,4]$. Several reports have 
shown that mouse strains with different $\mathrm{H}-2$ haplotypes can be divided into responders and non-responders, dependent on the species of insulin used for immunization [3-6].

Transgenic mice have already made possible the evaluation of numerous hypotheses on how immunological tolerance to self proteins is developed, maintained or broken and several comprehensive reviews are available [7-12]. The use of transgenic mice in the study of the pathogenesis of insulin-dependent diabetes mellitus has also been reviewed [13]. In this report we evaluate the use of transgenic mice that have tissue-specific expression of human insulin in the pancreatic beta cells [14-16] and are tolerant to human insulin, as a model with which to evaluate the potential immunogenicity of recombinant-produced insulin and insulin analogues. We did not aim to determine whether the tolerance in transgenic mice toward human insulin is due to T-cell tolerance or Bcell tolerance, or both, but focused entirely on antibody production as a parameter to evaluate the immune response. The results indicate that transgenic mice are useful as in vivo models for mapping immunogenic areas of recombinant proteins.

\section{Materials and methods}

Mice. Adult female BALB/c mice used for breeding and 6week-old inbred male mice (BALB/c $\left(\mathrm{H}-2^{\mathrm{d}}\right), \mathrm{DBA} / 2\left(\mathrm{H}-2^{\mathrm{d}}\right)$, $\mathrm{C} 57 \mathrm{BL} / 6\left(\mathrm{H}-2^{\mathrm{b}}\right), \mathrm{CBA} / \mathrm{J}\left(\mathrm{H}-2^{\mathrm{k}}\right)$ and SJL/N $\left.\left(\mathrm{H}-2^{\mathrm{s}}\right)\right)$ and $\mathrm{F} 1-\mathrm{hy}-$ brids $\left(\mathrm{C} 57 \mathrm{BL} / 6 \times \mathrm{CBA} / \mathrm{J}\left(\mathrm{H}-2^{\mathrm{b} / \mathrm{k}}\right)\right.$ and BALB/c $\times \mathrm{C} 57 \mathrm{BL} / 6(\mathrm{H}-$ $\left.2^{\mathrm{d} / \mathrm{b}}\right)$ ) used for immunization experiments were obtained from Bomholtgaard Breeding and Research Centre Ltd., Ry, Denmark. The inbred and F1-hybrid mice were acclimatized 3 weeks before entering the immunization study at an age of 9 weeks. The transgenic mouse line (line 171) used for breeding in this study has previously been described [14-17]. Briefly, the transgenic mice are the progeny of the original founder mouse produced by microinjecting an 11-kilobase human chromosomal DNA fragment including the insulin gene (1430 base pairs) into fertilized mouse eggs [14]. The human DNA fragments, arranged in head-to-tail arrays, are located on chromosome 18 [15]. The transgenic mice from line 171 are C57BL/ $6 \times$ CBA F2 mice backcrossed for more than 10 generations with $\mathrm{C} 57 \mathrm{BL} / 6\left(\mathrm{H}-2^{\mathrm{b}}\right)$. The transgenic mice have tissue-specific expression in the pancreatic beta cells [16]. Expression of human insulin measured as percent of total insulin in the islets of Langerhans is approximately $50 \%$ [17]. For this study the transgenic mice were backcrossed with normal BALB/c mice. Transgenic F1 offspring were identified by either dot-blot assay or polymerase chain reaction (PCR) on tail DNA purified as described elsewhere [18]. DNA samples from selected mice were further analysed by digestion with the restriction enzyme $B g l I I$ and Southern blot analysis using standard protocols [19]. Both dot-blot and Southern blot were hybridized with a probe radiolabelled by random priming [20], using a 1.1 kilobase Hind III fragment, containing the $875 /+241$ segment of the human insulin gene [21].

PCR screening was performed using standard methods [22]. The amplification of the mouse proinsulin gene II was used as the internal control for the PCR reaction. The $5^{\prime}$ primer for the human insulin gene (GGGGCGGGGGAAG-
GAGG) and for the mouse insulin II gene (TAAGGGGCGAGAAAACCTGGGGTAG) are sequences located in the intron 2 of the corresponding genes. The $3^{\prime}$ primer (AGTTGCAGTAGTTCTCCAG) was common for the two genes and located in the exon 3. A two-step PCR cycle was used, with annealing temperatures of $59^{\circ} \mathrm{C}$ and $58^{\circ} \mathrm{C}$. Amplification products were 248 base pair for the mouse gene and 359 base pair for the human gene. The expression of the human insulin gene was verified by measuring human C-peptide in urine or blood using a commercially available radioimmunoassay kit (Novo Biolabs Denmark, cat.no. 735 143 7) with ${ }^{125}$ I labelled synthetic human Tyr-C-peptide and anti-synthetic human $\mathrm{C}$ peptide guinea-pig serum.

Non-transgenic controls were either non-transgenic F1 littermates or $\mathrm{BALB} / \mathrm{c} \times \mathrm{C} 57 \mathrm{BL} / 6 \mathrm{~F} 1$-hybrids. No differences were detected between these two control groups.

All mice were maintained under controlled temperature $\left(20-22^{\circ} \mathrm{C}\right)$, light (lights on $06.00-18.00$ hours) and relative humidity $(50-70 \%)$. The mice were fed ad libitum with Altromin 1324 (Chr. Petersen, Ringsted, Denmark).

Antigens and immunization. Rat I/II (2:1), bovine and porcine insulins were prepared chromatographically from material of pancreatic origin. The highly purified recombinant human insulin and insulin analogues studied are molecules for which substitutions have been engineered by oligonucleotide directed mutagenesis or by total gene synthesis and produced in saccharomyces cerevisiae. The sites A8 and A10 represent the differences between bovine insulin and porcine insulin. Substitution of A21 and B3 was performed to obtain chemical stability [23, 24]. Substitution of $B 9, B 27$ or B28 and deletion of $B 27$ were engineered to obtain monomeric analogues $[25,26]$. All insulins were dissolved in phosphate buffered saline to a concentration of $17.5 \mu \mathrm{mol} / \mathrm{l}$. The amino acid differences between the insulins and insulin analogues used in this study are shown in Figure 1.

Each group of mice was immunized intraperitoneally with $3.5 \mathrm{nmol}$ insulin per mouse, given in a volume of $400 \mu \mathrm{l}$ in a 1:1 ratio with complete Freund's adjuvant (Difco Laboratories, Detroit, Mich., USA). A secondary immunization with $3.5 \mathrm{nmol}$ insulin per mouse was given intraperitoneally on day 21 without adjuvant in a volume of $200 \mu \mathrm{l}$. On day 0 and day 30 , blood was taken from the retro orbital sinus and sera prepared for assay.

Antibody assay. Using a radioimmunoassay (RIA) insulin antibodies were monitored in serum samples, that were centrifuged at $2620 \mathrm{~g}$ for $10 \mathrm{~min}$ at $4{ }^{\circ} \mathrm{C}$ before analysis. Ten $\mu \mathrm{l}$ was incubated with $200 \mu 1$ of ${ }^{125} \mathrm{I}$ monoiodoinsulin preparation (human, rat, bovine, porcine or one of the analogues). For all preparations the tyrosine-residue A14 was labelled. The tracer preparations contained approximately $40000 \mathrm{cpm}(10$ $\mathrm{fmol}$ ) in $0.040 \mathrm{~mol} / \mathrm{l}$ phosphate buffer, $\mathrm{pH} 7.4$ with $0.10 \mathrm{~mol} / \mathrm{l}$ $\mathrm{NaCl}, 0.01 \mathrm{~mol} / 1 \mathrm{EDTA}$ and $0.25 \%$ bovine gammaglobulin. After $18 \mathrm{~h}$ at $4{ }^{\circ} \mathrm{C}$, incubation was stopped by the addition of a precipitating reagent containing $17.5 \%$ polyethyleneglycol (PEG) 6000 and $0.1 \%$ Tween 20 in $0.05 \mathrm{~mol} / 1$ 5,5-diethyl barbituric acid buffer, $\mathrm{pH}$ 8.4. Subsequent centrifugation was carried out at $4660 \mathrm{~g}$ for $20 \mathrm{~min}$ at $4^{\circ} \mathrm{C}$. After removal of the supernatant and washing of the precipitate with $1.4 \mathrm{ml}$ of precipitating reagent, the centrifugation procedure was repeated.

The fraction of total radioactivity in the pellet represents bound antigen. Day 30 samples were considered to give a positive result, if they were more than twice the value of the day 0 sample.

To determine antibody class a colorimetric enzyme linked immunosorbent assay (ELISA) was used. In short, the relevant insulin or analogue was coated to microtitre plates 
A-chain

Human

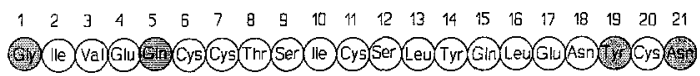

MouselRat $1+1 \mid$

Porcine

Eovine

A.BA

A10V

$\mathrm{ABH}$

B280

B27E

B9D

B9DIE27E

A21G

A21A

B27-

A21G]B3DIB27

A

B-chain

Hurmas

Mouse:Pas I

Mouse: Rât It

Forcine

Eovine

ABA

A10V

ABH

$B 280$

근

890

घ9DiBa?

A21G

A.21A

A21G18301927

B AzLie3тté

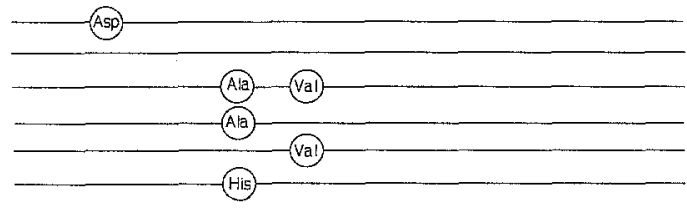

Fig. 1. (A,B) The amino acid sequence in $\mathbf{A}$ ) the A-chain and B) the B-chain of human insulin and the amino acid differences in mouse, bovine and porcine insulins [28] and insulin analogues used in this study. The analogues are named after the positions in the $\mathrm{A}$ and $\mathrm{B}$ chain where the substitutions/deletions have been made; e.g., in analogue B9D/B27E the amino acids serine ( $\mathrm{S}$ ) and threonine $(\mathrm{T})$ in human insulin at position 9 and 27 in the B chain have been substituted with the amino acids aspartate (D) and glutamate (E). Putative sites interacting with the receptor are indicated with grey residues [33]. /, Amino acid deletion

(Cat.no. 439454, Nunc, Roskilde, Denmark) at a concentration of $0.5 \mu \mathrm{g} / \mathrm{ml}$ in $0.1 \mathrm{~mol} / 1$ Tris buffer $\mathrm{pH} 8.6$. Incubation on a shaker for $60-75 \mathrm{~min}$ at room temperature $\left(20-22^{\circ} \mathrm{C}\right)$ was performed with the plasma sample diluted 1:500. Affinity isolated antibodies to either mouse IgG $\gamma$-chain (Sigma A3673 $1: 10000$ ) or IgM $\mu$-chain (Sigma A8786 1:10000) were used for qualitative estimation of sub-class. The conjugates were labelled with peroxidase and the enzyme was monitored by incu-

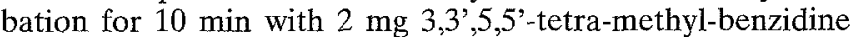
(Sigma T-3405) per plate, dissolved in $14 \mathrm{ml} 0.0032 \mathrm{~mol} / 1 \mathrm{per}$ borate in $0.04 \mathrm{~mol} / 1$ acetate buffer $\mathrm{pH} 5.0$. Colour development was measured at $450 \mathrm{~nm}$ using a microplate reader. Day 30 samples were considered positive if the optical density (OD) value at $450 \mathrm{~nm}$ was more than twice the $O D$ value for day 0 samples (both diluted 1:500).

\section{Statistical analysis}

Mann-Whitney U test was used for each group to compare the antibody response in transgenic mice with the antibody response in non-transgenic controls.

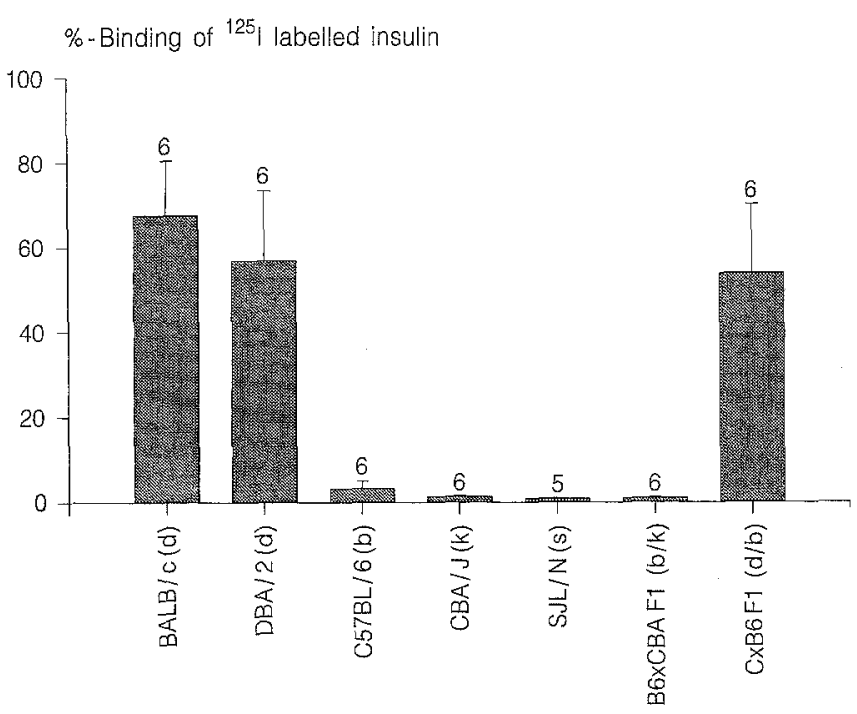

Fig. 2. Antibody responses to recombinant human insulin. Inbred strains of mice and F1 hybrids were immunized intraperitoneally on day 0 and on day 21 with human insulin. Sera were collected on day 30 . The numbers of mice per group are shown above the error bars and the $\mathrm{H}-2$ haplotypes are shown in parentheses. Data are presented as the groups' mean $\%$-binding of ${ }^{125} \mathrm{I}$ labelled human insulin \pm SEM. $(\mathrm{B} 6 \times \mathrm{CBA}) \mathrm{F} 1:(\mathrm{C} 57 \mathrm{BL} / 6 \times \mathrm{CBA}) \mathrm{F} 1 ; \quad(\mathrm{C} \times \mathrm{B} 6) \mathrm{F} 1:(\mathrm{BALB} /$ $\mathrm{c} \times \mathrm{C} 57 \mathrm{BL} / 6) \mathrm{F} 1$

\section{Results}

Immune response to insulin in mice. In order to verify that the non-transgenic control mice were responders (positive control), i.e. produce antibodies against human insulin, different mouse strains and F1-hybrids were immunized with human insulin. It has been shown that normal $\mathrm{H}-2^{\mathrm{d}}, \mathrm{H}-2^{\mathrm{d} / \mathrm{k}}$ and $\mathrm{H}-2^{\mathrm{k} / \mathrm{b}}$ mice respond to human insulin, whereas $\mathrm{H}-2^{\mathrm{b}}$ and $\mathrm{H}-2^{\mathrm{k}}$ mice do not [27]. Our results (Fig.2) show that inbred mice with haplotype $\mathrm{H}-2^{\mathrm{d}}$ respond, whereas inbred mice with haplotype $\mathrm{H}-2^{\mathrm{b}}, \mathrm{H}-2^{\mathrm{k}}$ and $\mathrm{H}-2^{\mathrm{s}}$ do not respond with insulin antibodies to human insulin. We also found that the F1-generation, after a cross between a nonresponder $\left(\mathrm{H}-2^{\mathrm{b}}\right)$ and a responder $(\mathrm{H}-$ $\left.2^{\mathrm{d}}\right)$, responds with antibody production, whereas the F1-generation after a cross between two non-responder mice $\left(\mathrm{H}-2^{\mathrm{b}} \times \mathrm{H}-2^{\mathrm{k}}\right)$ does not respond with insulin antibodies.

Since the F1 generation obtained from a cross between non-responder and responder haplotypes was shown to be able to produce antibodies against human insulin, further experiments used F1 animals obtained by crossing the transgenic mice with $\mathrm{BALB} / \mathrm{c}$ mice yielding a $\mathrm{H}-2^{\mathrm{d} / \mathrm{b}}$ responder haplotype.

Tolerance to human insulin in transgenic mice. In an initial experiment 27 transgenic F1 mice and 15 nontransgenic littermates were immunized with human insulin. None of the 42 mice possessed antibodies against insulin in the serum samples on day 0 . The 
RIA results (Table 1 ) showed that only 1 of 27 transgenic mice responded with antibodies against human insulin, whereas 11 of 15 non-transgenic mice produced insulin antibodies. These results were confirmed in the $\operatorname{IgG}$ ELISA test except for a single transgenic mouse, where a small titre was detected in the ELISA test (data not shown). To demonstrate that the non-responding transgenic mice have the capability of producing antibodies against other proteins, 10 of the transgenic mice, which were tolerant to human insulin, were immunized with bovine insulin. All 10 transgenic mice responded with antibodies against insulin in the serum samples on day 30 , when tested with ELISA and RIA (42.2 $\pm 10.4 \%$-binding of ${ }^{125} \mathrm{I}$ labelled insulin), indicating that the tolerance to human insulin was not due to a generalized defect in the immune system.

Immunization with insulin analogues. Twelve insulin analogues, which only differ from human insulin in 1-3 amino acid residues (Fig. 1), were chosen to evaluate whether transgenic mice tolerant to human insulin would produce antibodies directed against these amino acid substitutions in human insulin. Human insulin was used as a negative control in transgenic mice. Rat insulin was used to show that the mouse immune system is self-tolerant since rat and mouse insulins are identical [28]. Bovine insulin was tested as a positive control, and porcine insulin was used as an example of an insulin preparation with only one amino acid different from human insulin.

The RIA results (Fig. 3) showed that the transgenic mice only developed antibodies when they were immunized with bovine insulin and the three analogues A8A, A8H and A10V. All nontransgenic control groups produced antibodies to all insulins and analogues with the exception of rat insulin. Two out of 14 transgenic mice responded to porcine insulin (respectively 2.9 and $39.3 \%$-binding of ${ }^{125} \mathrm{I}$ labelled porcine insulin). The ELISA test for IgG antibodies confirmed these results, apart from two transgenic mice which responded with a small titre to the analogue A21G/B3D/B27-. Most of the IgG antibodies were found to be of the $\operatorname{IgG} 1$ isotype (data not shown).

When analysed in ELISA for IgM antibodies all groups except those immunized with porcine insulin had mean OD values (dilution 1:500) on day 30 which were more than twice the mean value of day 0 samples (Table 2).

In order to demonstrate whether the IgM antibodies were developed because of the strong unspecific stimulation of the immune system using adjuvant, 10 transgenic and 10 non-transgenic mice were immunized with Freund's complete adjuvant and phosphate buffered saline instead of insulin (see Methods). Sera from these mice were analysed for IgG and IgM antibodies against human insulin, rat insulin and mouse albumin (Sigma A3559) by ELISA;
Table 1. Antibody response against human insulin after immunization of transgenic mice and control mice

\begin{tabular}{lcc}
\hline & Transgenic & Non-transgenic \\
\hline Response & $1 / 27(63.7)$ & $11 / 15(51.9 \pm 9.1)$ \\
No response & $26 / 27(0.8 \pm 0.04)$ & $4 / 15(1.1 \pm 0.2)$ \\
\hline
\end{tabular}

Twenty seven transgenic mice and 15 non-transgenic mice were immunized with human insulin. The mean \%-binding of ${ }^{125}$ I labelled human insulin \pm SEM is shown in parentheses

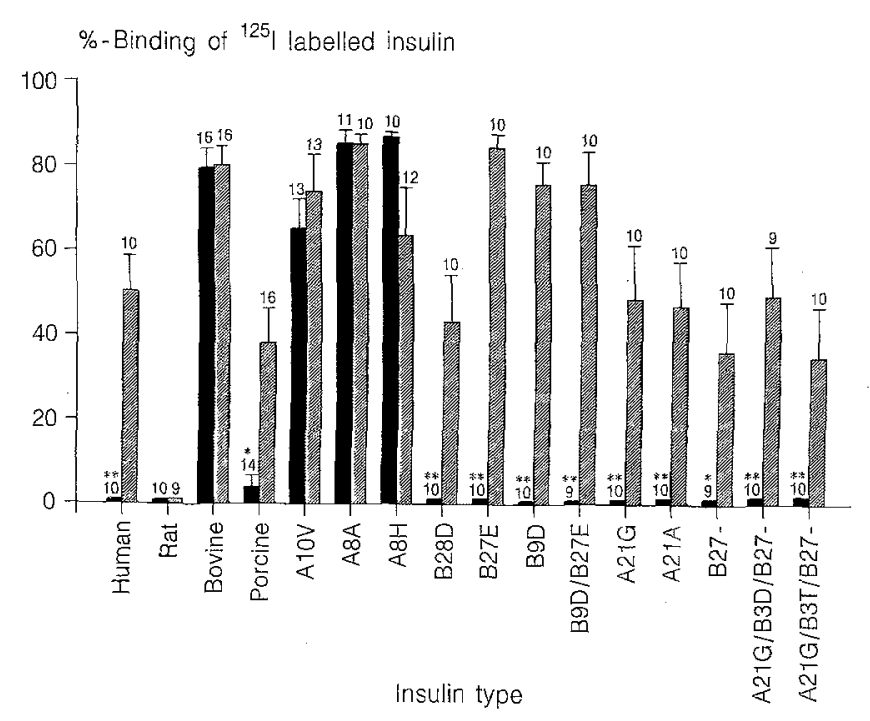

Fig.3. Antibody responses to insulins and insulin analogues in transgenic mice (D) and nontransgenic controls (圂). The numbers of mice per group are shown above the error bars. Data are presented as the groups mean \%-binding of ${ }^{125} \mathrm{Y}$ labelled insulin/analogue \pm SEM. Asterisks above transgenic groups indicate that these groups are significantly different from the corresponding non-transgenic groups; * $p<0.03$; $* * p<0.001$; no asterisk $p>0.05$

No IgG antibodies were detected. The IgM results (Table 3) show that IgM antibodies cross-reactive with human insulin and rat insulin developed, whereas no antibodies developed against mouse albumin when adjuvant was used.

Cross-reacting antibodies. To test whether antibodies produced against analogues were cross-reactive with human insulin, sera from two non-transgenic mice from each of the 12 groups immunized with analogues, and sera from four transgenic mice immunized with analogue A10V were tested. The RIA and ELISA were performed as described in Methods with the exception that human insulin instead of the relevant analogue was used as tracer or used to coat the microtitre plates, respectively. The results (Table 4) show that all 24 non-transgenic serum samples from day 30 contained antibodies cross-reactive with human insulin by both RIA and ELISA. Serum from the four transgenic mice that developed antibodies against analogue $\mathrm{A} 10 \mathrm{~V}$ also contained cross-reactive antibodies. 
Table 2. Number of transgenic mice and non-transgenic control mice responding with an IgG and/or IgM antibody response against insulins and analogues in ELISA

\begin{tabular}{|c|c|c|c|c|}
\hline \multirow[t]{2}{*}{ Immunogen } & \multicolumn{2}{|l|}{ Transgenic } & \multicolumn{2}{|c|}{ Non-transgenic } \\
\hline & $\operatorname{IgG}$ & $\operatorname{IgM}$ & $\mathrm{IgG}$ & $\operatorname{IgM}$ \\
\hline Human & $0 / 10(1.0)$ & $6 / 10(2.7)$ & $9 / 10(17.9)$ & $5 / 10(3.7)$ \\
\hline Rat & $0 / 10(1.0)$ & $5 / 10(3.0)$ & $0 / 10(1.1)$ & $4 / 10(2.5)$ \\
\hline Bovine & $15 / 16(32.6)$ & $16 / 16(7.9)$ & $15 / 15(38.0)$ & $7 / 15(3.0)$ \\
\hline Porcine & $2 / 14$ & $1 / 14(1.2)$ & 10/14 (18.6) & $0 / 14(1.4)$ \\
\hline $\mathrm{A} 21 \mathrm{G}$ & $0 / 10(1.1)$ & $2 / 10(2.2)$ & $7 / 10(18.6)$ & $2 / 10(2.1)$ \\
\hline A21A & $0 / 10(1.1)$ & $6 / 10(2.2)$ & $9 / 10(23.7)$ & $7 / 10(2.7)$ \\
\hline B28D & $0 / 10(1.1)$ & $5 / 10(2.4)$ & $9 / 10(21.9)$ & $6 / 10(2.1)$ \\
\hline B27- & $0 / 9 \quad(0.9)$ & $7 / 9 \quad(4.3)$ & $8 / 10$ (19.4) & $8 / 10(2.4)$ \\
\hline $\mathrm{A} 21 \mathrm{G} / \mathrm{B} 3 \mathrm{D} / \mathrm{B} 27$ & $2 / 10(1.8)$ & $8 / 10(3.2)$ & $7 / 9 \quad(22.8)$ & $5 / 9 \quad(2.3)$ \\
\hline A21G/B3T/B27- & $0 / 10(0.9)$ & $5 / 10(2.6)$ & $8 / 10(15.1)$ & $6 / 10(4.1)$ \\
\hline B27E & $0 / 10(1.0)$ & $6 / 10(3.7)$ & $10 / 10(39.2)$ & $8 / 10(4.1)$ \\
\hline B9D/B27E & $0 / 9 \quad(1.1)$ & $4 / 9 \quad(3.6)$ & $9 / 10(29.2)$ & $7 / 10(3.3)$ \\
\hline B9D & $0 / 10(1.0)$ & $6 / 10(2.8)$ & $10 / 10(37.4)$ & $8 / 10(3.0)$ \\
\hline $\mathrm{A} 8 \mathrm{H}$ & nd & nd & $8 / 10(25.8)$ & $7 / 10(5.8)$ \\
\hline A8A & nd & nd & $10 / 10(41.7)$ & $6 / 10(4.5)$ \\
\hline $\mathrm{A} 10 \mathrm{~V}$ & $4 / 5 \quad(21.6)$ & $4 / 5 \quad(4.6)$ & $8 / 10(32.5)$ & $8 / 10(4.5)$ \\
\hline
\end{tabular}

The ratio between the mean OD value for day 30 samples and the mean OD value for day 0 samples in a 1:500 dilution is shown in parentheses. The mean OD value \pm SEM for all day 0 samples was $0.072 \pm 0.001$. nd, not done

Table 3. Number of transgenic mice and non-transgenic control mice responding with IgM antibodies that cross-react with human insulin, rat insulin and mouse albumin in ELISA after immunization with adjuvant

\begin{tabular}{lll}
\hline ELISA plate coating & $\begin{array}{l}\text { Transgenic } \\
\text { IgM }\end{array}$ & $\begin{array}{l}\text { Non-transgenic } \\
\operatorname{IgM}\end{array}$ \\
\hline Human insulin & $8 / 10(2.9)$ & $2 / 10(1.7)$ \\
Rat insulin & $6 / 10(2.5)$ & $3 / 10(1.9)$ \\
Mouse albumin & $0 / 10(1.2)$ & $0 / 10(1.1)$ \\
\hline
\end{tabular}

The ratio between the mean OD value for day 30 samples and the mean $O D$ value for day 0 samples in a 1:500 dilution is shown in parentheses

\section{Discussion}

The production of insulin antibodies after insulin injection has been reported to play a role in the development of local and systemic allergic reactions, injection-site lipoatrophy and some types of insulin resistance as well as having more subtle effects on the dose requirement and on the pharmacokinetics of injected insulin [1]. It is therefore of paramount importance to document that therapeutic insulin is unlikely to cause antibody formation. Availability of recombinant techniques to produce analogues, with better in vivo characteristics, has highlighted the need for assessment of the potential immunogenicity of these second generation proteins.

Traditionally, the potential immunogenicity of recombinant or native insulins has been tested in laboratory animals (e.g., mice, rats or rabbits) with subsequent evaluation of the antibody response in the animals, based on previous experience of how the animals respond to known immunogenic and non-im-
Table 4. Cross-reacting antibodies against human insulin in sera from two non-transgenic mice from each of the 12 groups immunized with analogues (Table 1) and sera from four responding transgenic mice immunized with analogue $\mathrm{A} 10 \mathrm{~V}$

\begin{tabular}{|c|c|c|c|c|}
\hline \multirow{2}{*}{$\begin{array}{l}\text { Immunogen } \\
\mathrm{A} 21 \mathrm{G}\end{array}$} & \multicolumn{2}{|l|}{ RIA } & \multicolumn{2}{|c|}{ ELISA } \\
\hline & 54.7 & 74.9 & 14.5 & 27.0 \\
\hline $\mathrm{A} 21 \mathrm{~A}$ & 50.2 & 41.2 & 38.6 & 13.5 \\
\hline $\mathrm{B} 28 \mathrm{D}$ & 69.6 & 68.0 & 39.1 & 41.5 \\
\hline B27. & 77.6 & 70.2 & 20.4 & 41.1 \\
\hline A21G/B3D/B27- & 57.5 & 33.3 & 28.9 & 10.2 \\
\hline A21G/B3T/B27- & 78.4 & 55.7 & 38.6 & 18.3 \\
\hline $\mathrm{B} 27 \mathrm{E}$ & 83.8 & 87.4 & 40.4 & 47.6 \\
\hline B9D/B27E & 18.3 & 38.9 & 2.0 & 13.2 \\
\hline B9D & 86.2 & 62.8 & 44.6 & 12.3 \\
\hline $\mathrm{A} 8 \mathrm{H}$ & 87.4 & 84.4 & 39.5 & 36.6 \\
\hline A8A & 77.2 & 57.3 & 42.1 & 37.3 \\
\hline A10V & 87.2 & 72.0 & 28.7 & 39.7 \\
\hline TG: & 40.4 & 28.5 & 23.5 & 19.5 \\
\hline TG: & 64.1 & 54.1 & 37.1 & 33.9 \\
\hline
\end{tabular}

The RIA data are presented as \%-binding of ${ }^{125} \mathrm{I}$ labelled human insulin (the mean \%-binding of ${ }^{125}$ I labelled human insulin in the 28 preimmune serum samples was $1.1 \pm 0.06$ ). ELISA-data are presented as the ratio between the OD value for the day 30 sample and the OD value for the day 0 sample in a 1:500 dilution. TG, Transgenic mice

munogenic preparations [1, 3, 29-31]. Historically a high antibody titre in rabbits immunized with an insulin preparation is known often to predict a similar result in humans injected with the same preparation $[29,30,32]$. In the absence of a more appropriate model, rabbits have therefore been used to evaluate the potential immunogenicity of recombinant insulins and insulin analogues [33].

The main advantage of using transgenic mice as immunogenicity models is that tolerance to the na- 
tive protein has been induced by physiological levels of the protein from early stages of embryonic development. Sometimes the only way to discover the immunogenicity of a protein has been to retrospectively evaluate the response after administration of the protein to patients.

An in vitro priming assay in which peripheral blood lymphocytes from normal humans are primed with insulin prior to challenge with insulin in conjunction with autologous antigen-presenting cells has been reported as a model with which to evaluate the cellular immune response [34]. Since there is considerable heterogeneity in the lymphocyte responses in human individuals, it is difficult to standardize this assay.

The results obtained with different mouse strains and F1-hybrids immunized with human insulin confirm the observations by Whiteley et al. [27] and extend the knowledge of how various inbred strains of mice respond to human insulin. Our observation that the F1-generation after a cross between two non-responder mice $\left(\mathrm{H}-2^{\mathrm{b}} \times \mathrm{H}-2^{\mathrm{k}}\right)$ do not develop insulin antibodies after immunization with human insulin (Fig. 2) seems to be in contrast with the results by Whiteley et al. [27], who state that $\mathrm{H}-2^{\mathrm{k} / \mathrm{b}}$ mice respond to human insulin. Both results are in accordance with observations by Keck [4], who showed that immunization with porcine insulin to the F1 generation of mice with the same $\mathrm{H}-2$ haplotype $\left(\mathrm{H}-2^{\mathrm{k} / \mathrm{b}}\right)$, but derived from different strains of non-responder mice, resulted in an antibody response, if one of the strains had $\mathrm{C} 3 \mathrm{H}\left(\mathrm{H}-2^{\mathrm{k}}\right)$ background, as the strain used by Whiteley et al., while no antibody response was seen if $(\mathrm{C} 57 \mathrm{BL} / 10 \times \mathrm{B} 10 . \mathrm{BR}) \mathrm{F} 1$ mice, that also have the $\mathrm{H}-2^{\mathrm{k} / \mathrm{b}}$ haplotype, were used. So the combination of the two $\mathrm{H}-2$ haplotypes alone is not always sufficient to effect complementation [4].

It could be argued that the immunization protocol, where adjuvant is used, cannot be directly compared with the daily injections of insulin without adjuvant used in the clinic. To demonstrate whether adjuvant is necessary to stimulate the immune system as seen in the rabbit model [31], control mice were injected subcutaneously three times a week with human or bovine insulin without the use of adjuvant. Glucose was administered to prevent seizures. An antibody response against both human and bovine insulin was seen in RIA after 21 to 42 days, but the \%-binding of ${ }^{125}$-I labelled insulin was lower than when complete Freund's adjuvant was used (J.L. Ottesen, P. Nilsson, unpublished observations). These results demonstrate that it is possible to use an immunization protocol without the use of adjuvant to elicit an antibody response, but since the aim of the model is to detect immunogenic epitopes, which could ultimately result in an antibody response after daily injections to humans over many years, the immune system in an accelerated animal model system should be maximally stimulated. It has been reported that primary immunization with insulin elicits predominantly insulin-specific IgG and not IgM antibodies $[35,36]$. When the samples in this study were analysed in the ELISA test for IgM antibodies, approximately $50 \%$ of the mice in all groups (including mice immunized with rat insulin) responded with low, but significant titres. This low IgM response is probably due to low affinity antibodies of minor significance in the animal, developed because of nonspecific stimulation of the immune system when Freund's complete adjuvant is used.

Traditionally, diabetic patients have been treated with bovine or porcine insulins and within the last 10 years also with recombinant human insulin. Clinical trials with patients receiving recombinant human insulin or highly purified porcine insulin, which only differs from human insulin at position B30, showed that there was no difference between the patient groups in the percentage of patients with insulin antibodies [37, 38], but porcine monocomponent insulin resulted in higher antibody titres than monocomponent human insulin [37-41].

Bovine insulin, which differs from human insulin at positions A8, A10 and B30 is, even in a highly purified form, still more immunogenic in patients than recombinant human and porcine insulins $[37,40,42]$. The results obiained with transgenic mice immunized with human, porcine or bovine insulins are similar to those obtained with insulin administration to patients in clinical trials $[37,42]$. Even though the titres are generally low, antibodies against human and porcine insulins are found in patients [38].

Bovine and porcine insulin only differ from each other at position A8 and A10 in the A-chain loop [5]. It has never been known whether one or both of these amino acid residues are necessary to elicit antibody formation. The results presented here, with the three insulin analogues $\mathrm{A} 8 \mathrm{~A}, \mathrm{~A} 10 \mathrm{~V}$ and $\mathrm{A} 8 \mathrm{H}$, provide the first in vivo indication that only one single amino acid substitution in the A-chain loop at position $\mathrm{A} 8$ or $\mathrm{A} 10$ is sufficient to elicit an immune reaction in responder mice. Analogues $\mathrm{A} 8 \mathrm{H}, \mathrm{A} 8 \mathrm{~A}$ and $\mathrm{A} 10 \mathrm{~V}$ were prepared with the aim of studying the effect of single substitutions in the A-chain loop. The other insulin analogues used in this study were made by amino acid substitutions or deletions either designed to prevent hexamer formation $[25,26]$ or to improve chemical stability $[23,24]$, without destabilizing their own three-dimensional structure or interfering with their biological activity $[23,25,33,43]$.

Antibodies induced by various insulins are extremely cross-reactive [27, 44]. Antibodies developed against all the analogues used in this study have cross-reactivity against human insulin. Since antibodies induced by analogues cross-react with human insulin it is of paramount importance that analogues can be evaluated in a model and be shown to be non-immunogenic before they are used in clinical 
trials. In cases where the altered protein is administered to supplement a low level of endogenous protein, cross-reactive antibodies might neutralize the effect of both the endogenous protein and the altered protein and by that aggravate the condition for which the protein was given. Inhibitor antibodies causing a problem in therapy are known from the clinical situation in the treatment of haemophilia A and $\mathrm{B}$ patients with coagulation factor VIII and factor IX, respectively [45].

Stewart et al. [2] used mice transgenic with the gene for human tissue plasminogen activator (htPA), a serine protease with 527 amino acids, to test the immunogenicity of a protein that had been altered by site-specific mutagenesis. They immunized transgenic mice and non-transgenic control mice with htPA or htPA with one single amino acid substitution. The results showed that the transgenic mice (in contrast to non-transgenic mice) were tolerant to htPA, whereas half of the transgenic mice immunized with mutated htPA produced antibodies. They further demonstrated that antibodies developed toward the mutated htPA cross reacted with htPA.

Application of genetically identical transgenic mice in studies aimed at determining the risk of immunological response in humans has the merits of a model. This means that the MHC class II locus is known and that the strains selected respond to an immunological challenge in a well-defined way. The human population subjected to treatment with the biosynthetic product will display a high degree of polymorphism. A distinct result in the transgenic model would therefore not necessarily be as distinct in humans, but if transgenic mice produce antibodies to an altered human protein it seems likely that there will be a number of subjects in the human population, who will also respond to this epitope [2].

In transgenic mice where the transgene product shows less similarity with the endogenous gene product than is the case with human and mouse insulin, a potential source of error could be that amino acid substitutions in the human protein will resemble epitopes on the endogenous mouse protein. In this case the mouse immune system will recognize the epitopes as self, and no antibody response will be elicited. This problem could be overcome by knock out of the endogenous mouse gene by gene targeting in embryonic stem cells $[46,47]$.

It should be emphasized that the immunization protocol, the MHC haplotype of the mouse strain and the detection assay should be carefully evaluated before transgenic mice are used as immunogenicity models for altered second generation proteins.

The development of new recombinant insulin analogues, to address specific diabetic treatments, entails the need to evaluate a potential immunogenicity of the altered native insulin. The transgenic mouse immunogenicity model presents an in vivo assay for this testing purpose. One must, however, keep in mind that no matter which models are used, in the end only long-term clinical trials will be able to confirm whether a recombinantly produced analogue is immunogenic.

Acknowledgements. We are grateful to Michel Seman, Paris University, for determination of the antibody class in the preliminary experiments. We also thank Mads Krogsgaard Thomsen, Novo Nordisk A/S, for critical review of the manuscript and Ulla Dahl Larsen, Novo Nordisk A/S, for ${ }^{125}$ I monoiodo insulin preparations. Finally we thank Ms. B. Walsøe Fetterlein, Ms. E. Jensen, Ms. B. Skafte, P. Jensen and Ms. E. Krøyer for skillful technical assistance.

\section{References}

1. Reeves WG (1983) Insulin antibody determination: theoretical and practical considerations. Diabetologia 24: 399-403

2. Stewart TA, Hollingshead PG, Pitts SL, Chang R, Martin LE, Oakley H (1989) Transgenic mice as a model to test the immunogenicity of proteins altered by site-specific mutagenesis. Mol Biol Med 6: 275-281

3. Keck K, Momayezi M (1980) Genetic regulation of the immune response of mice to insulins of different species. In: Brandenburg D, Wallmer A (eds) Insulin, chemistry, structure and function of insulin and related hormones. Watther de Gruyter, Berlin, pp 551-558

4. Keck K (1977) Ir gene control of carrier recognition. III. Cooperative recognititon of two or more carrier determinants of different species. Eur J Immunol 7: 811-816

5. Keck K (1975) Ir-gene control of immunogenicity of insulin and A-chain loop as a carrier determinant. Nature (Lond) 254: 78-79

6. Kapp JA, Strayer DS (1978) H-2 linked Ir gene control of antibody responses to porcine insulin. I. Development of insulin-specific antibodies in some but not all nonresponder strains injected with proinsulin. J Immunol 121:978-982

7. Hanahan D (1989) Transgenic mice as probes into complex systems. Science 246: 1265-1275

8. Adams TE (1990) Tolerance to self-antigens in transgenic mice. Mol Biol Med 7: 341-357

9. Miller JFAP, Morahan G, Allison J, Hoffmann M (1991) A transgenic approach to the study of peripheral T-cell tolerance. Immunol Rev 122: 103-116

10. Lo D, Burkley LC, Flavell RA, Palmiter RD, Brinster RL (1990) Antigen presentation in MHC class II transgenic mice: stimulation versus tolerization. Immunol Rev 117: 121-134

11. Basten A, Brink R, Peake P et al. (1991) Self tolerance in the B-cell repertoire. Immunol Rev 122: 5-19

12. Lo D, Freedman J, Hesse S, Brinster RL, Sherman L (1991) Peripheral tolerance in transgenic mice: tolerance to class II MHC and non-MHC transgene antigens. Immunol Rev 122: 87-102

13. Lipes MA, Eisenbarth GS (1990) Transgenic mouse models of type 1 diabetes. Diabetes 39: 879-884

14. Bucchini D, Ripoche MA, Stinnakre MG et al. (1986) Pancreatic expression of human insulin gene in transgenic mice. Proc Natl Acad Sci USA 83: 2511-2515

15. Michalova K, Bucchini D, Ripoche MA, Pictet R, Jami J (1988) Chromosome localization of the human insulin gene in transgenic mouse lines. Hum Genet 80: 247-252 
16. Bucchini D, Madsen O, Desbois P, Jami J, Pictet R (1989) B islet cells of pancreas are the site of expression of the human insulin gene in transgenic mice. Exp Cell Res 180: $467-474$

17. Fromont-Racine M, Bucchini D, Madsen O et al. (1990) Effect of $5^{\prime}$-flanking sequence deletions on expression of the human insulin gene in transgenic mice. Mol Endo 4: 669677

18. Laird PW, Zijderveld A, Linders K, Rudnicki MA, Janisch R, Berns A (1991) Simplified mammalian DNA isolation procedure. Nucleic Acids Res 19: 4293

19. Sambrook J, Fritsch EF, Maniatis T (1989) Molecular cloning: a laboratory manual. 2nd. edn. Cold Spring Harbor Laboratory Press, Cold Spring Harbor

20. Feinberg AP, Vogelstein B (1984) A technique for radiolabeling DNA restriction endonuclease fragments to high specific activity. Addendum Anal Biochem 137: 266-267

21. Bell GL, Pictet RL, Rutter WJ, Cordell B, Tischer E, Goodman HM (1989) Sequence of the human insulin gene. Nature 284: 26-32

22. Saiki RK (1990) Amplification of genomic DNA. In: Innis MA, Gelfand DH, Sniskky JJ, White TJ (eds) PCR protocols. A guide to methods and applications. Academic Press, San Diego, pp 13-20

23. Markussen J, Diers I, Hougaard P et al. (1988) Soluble, prolonged-acting insulin derivatives. III. Degree of protraction, crystallizability and chemical stability of insulins substituted in positions A21, B13, B23, B27 and B30. Protein Eng 2: 157-166

24. Brange J (1992) Chemical stability of insulin. 4. Mechanisms and kinetics of chemical transformations in pharmaceutical formulation. Acta Pharm Nord 4: 209-222

25. Brange J, Ribel U, Hansen JF et al. (1988) Monomeric insulins obtained by protein engineering and their medical implications. Nature 333: 679-682

26. Balschmidt P, Brange J (1992) Fast acting human insulin analogues with a single amino acid deletion in the B-chain (Abstract). Diabetologia 35 [Suppl 1]: A4

27. Whiteley PJ, Lake JP, Selden RF, Kapp JA (1989) Tolerance induced by physiological levels of secreted proteins in transgenic mice expressing human insulin. J Clin Invest 84: $1550-1554$

28. Dayhoff MO (1972) Atlas of protein sequence and structure, vol. 5. The National Medical Research Foundation, Washington

29. Hansen B (1981) Immunogenicity of insulin as a function of species and other factors. In: Gueriguian JL (ed) Insulins, growth hormone, and recombinant DNA technology. Raven Press, New York, pp 55-70

30. Kasama T, Iwata Y, Oshiro K et al. (1981) Antigenicity of desamido-insulin and monocomponent insulin. Diabetologia 21: 65-69

31. Schlichtkrull J, Brange J, Christiansen AH, Hallund O, Heding LG, Jørgensen KH (1972) Clinical aspects of insulin-antigenicity. Diabetes 21 [Suppl 2]: 649-656
32. Root MA, Chance RE, Galloway JA (1972) Immunogenicity of insulin. Diabetes 21 [Suppl 2]: 657-660

33. Brange J, Owens DR, Kang S, Vølund A (1990) Monomeric insulins and their experimental and clinical implications. Diabetes Care 13: 923-954

34. Parkar BA, Reeves WG (1989) In vitro priming of human lymphocytes to heterologous insulins. J Immunol Meth 120: $159-165$

35. Schroer JA, Inman JK, Thomas JW, Rosenthal AS (1979) $\mathrm{H}$-2-linked Ir gene control of antibody responses to insulin. I. Anti-insulin plaque-forming cell primary responses. J Immunol 123: 670-675

36. Jensen PE, Kapp JA (1984) Regulatory mechanisms of the immune response to heterologous insulins. I. Development and regulation of PFC responses in vitro. Cell Immunol 87: 73-84

37. Marshall MO, Heding LG, Villumsen J et al. (1988) Development of insulin antibodies, metabolic control and B-cell function in newly diagnosed insulin dependent diabetic children treated with monocomponent human insulin or monocomponent porcine insulin. Diabetes Res 9: 169-175

38. Zuppinger K, Aebi C, Fankhauser S et al. (1987) Comparison of human and porcine insulin therapies in children with newly diagnosed diabetes mellitus. Diabetologia 30 : 912-915

39. Heding LG, Marshall MO, Persson B et al. (1984) Immunogenicity of monocomponent human and porcine insulin in newly diagnosed type 1 (insulin-dependent) diabetic children. Diabetologia 27: 96-98

40. Reeves WG (1986) The immune response to insulin: characterisation and clinical consequences. In: Alberti KGMM, Krall LP (eds) The diabetes annual Vol 2. Elsevier Science Publishers, Amsterdam, pp 81-93

41. Schernthaner G, Borkenstein M, Fink M, Mayr WR, Menzel J, Schober E (1983) Immunogenicity of human insulin (Novo) or pork monocomponent insulin in HLA-DRtyped insulin-dependent diabetic individuals. Diabetes Care 6: 43-48

42. Reeves WG (1985) Immunogenicity of insulin of various origins. Neth J Med 28: 43-46

43. Vølund A, Brange J, Drejer K et al. (1991) In vitro and in vivo potency of insulin analogues designed for clinical use. Diabetic Med 8: 839-847

44. Whiteley PJ, Kapp JA (1989) Tolerance in transgenic mice to a non-MHC self-protein is not a result of clonal deletion. Progress in Immunol 7: 826-832

45. Roberts HR, Cromatie R (1984) Overview of inhibitors to factor VIII and IX. In: Hoyer LW (ed) Factor VIII inhibitors. Alan R. Liss, New York, pp 1-18

46. Capecchi MR (1989) Altering the genome by homologous recombination. Science 244: 1288-1292

47. Sedivy JM, Joyner AL (1992) Gene targeting. WH Freeman and Company, New York 